\title{
Density of Rhus michauxii Stems at Fort Pickett Military Reservation, Virginia
}

by Verl Emrick and Dr. Alison Hill

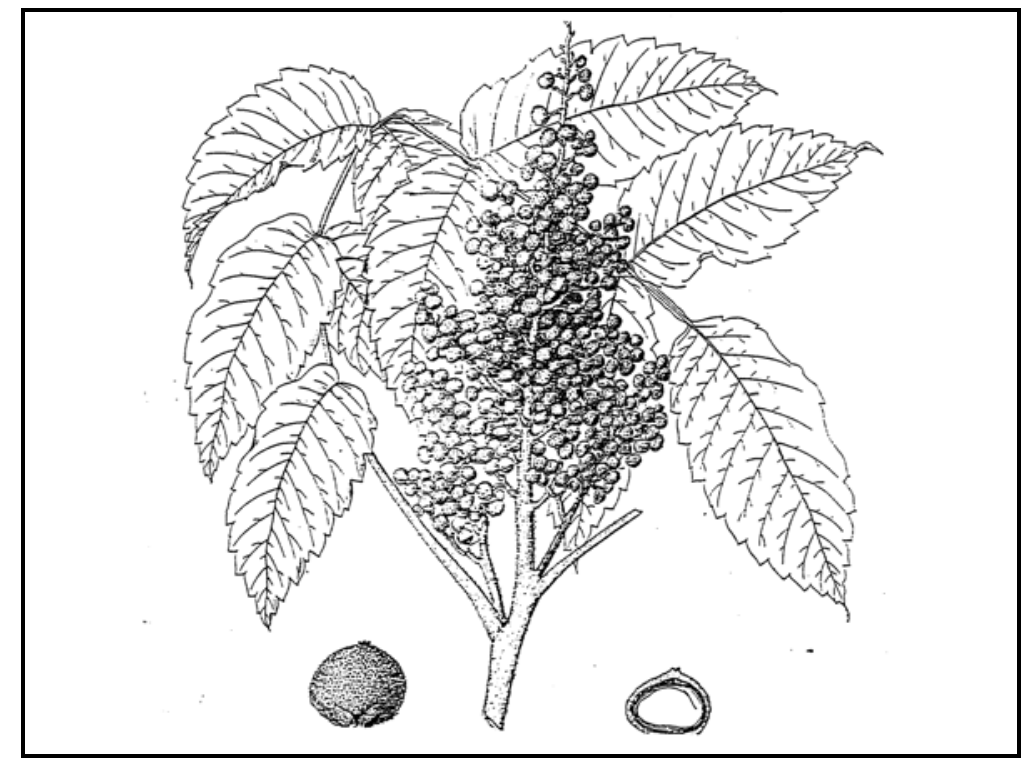

Rhus michauxii (Michaux's sumac), a Federally listed endangered species, was discovered at Fort Pickett Military Reservation, VA in 1993. Previous work had determined the locations of $R$. michauxii colonies and examined the composition and structure of plant communities where R. michauxii occurred. Fort Pickett natural resource managers needed baseline studies to characterize the ecology and population structure of $R$. michauxii for management purposes. This study was undertaken to determine the $R$. michauxii density in colonies on Fort Pickett, which has a critical role in maintaining the success of the population. Stem number was chosen as the most practical population measure given time and budget constraints and because of $R$. michauxii's rhizomatous nature. As a result, the stem density does not reflect the number of genets in the population.

Colonies were systematically sampled, using $2.5 \mathrm{~m}^{2}$ quadrats, for density of $R$. michauxii stems. The number of males, females, and gender-neutral stems were tallied in each quadrat. Mean density of $R$. michauxii stems was 1.39 stems $/ \mathrm{m}^{2}(+/-0.25)$. The density of flowering stems was significantly $(P<0.05)$ lower than gender-neutral stems. These findings were consistent with data from North Carolina populations. 
Public reporting burden for this collection of information is estimated to average 1 hour per response, including the lime for reviewing instructions, searching existing data sources, gathering and maintaining the data needed, and completing and reviewing the collection of information. Send comments regarding this burden estimate or any other aspect of this collection of information, including suggestions for reducing this burden, to Washington Headquarters Services, Directorate for information Operations and Reports, 1215 Jefferson Davis Highway, Suite 1204, Arlington, VA 22202-4302. and to the Office of Management and Budget, Papenwork Reduction Project (0704-0188), Washington, DC 20503.

\begin{tabular}{|c|c|c|}
\hline 1. AGENCY USE ONLY (Leave Blank) & $\begin{array}{l}\text { 2. REPORT DATE } \\
\text { July } 1997\end{array}$ & $\begin{array}{l}\text { 3. REPORT TYPE AND DATES COVERED } \\
\text { Final }\end{array}$ \\
\hline
\end{tabular}

4. TITLE AND SUBTITLE

Density of Rhus michauxii Stems at Fort Pickett Military Reservation, Virginia

5. FUNDING NUMBERS

MIPR

6JCERL0413

VB6

6. AUTHOR(S)

Verl Emrick and Dr. Alison Hill

7. PERFORMING ORGANIZATION NAME(S) AND ADDRESS(ES)

U.S. Army Construction Engineering Research Laboratories (USACERL)

P.O. Box 9005

Champaign, IL 61826-9005

8. PERFORMING ORGANIZATION REPORT NUMBER

TR $97 / 111$

9. SPONSORING / MONITORING AGENCY NAME(S) AND ADDRESS(ES)

Commander, U.S. Army Garrison Fort Pickett

ATTN: AFRC-FMP-PW

Fish and Wildlife Management Branch

Blackstone, VA 23824

11. SUPPLEMENTARY NOTES

Copies are available from the National Technical Information Service, 5285 Port Royal Road, Springfield, VA 22161.

12a. DISTRIBUTION / AVAILABILITY STATEMENT

12b. DISTRIBUTION CODE

Approved for public release; distribution is unlimited.

13. ABSTRACT (Maximum 200 words)

Rhus michauxii (Michaux's sumac), a Federally listed endangered species, was discovered at Fort Pickett Military

Reservation, VA in 1993. Previous work had determined the locations of $R$. michauxii colonies and examined the

composition and structure of plant communities where $R$. michauxii occurred. Fort Pickett natural resource managers

needed baseline studies to characterize the ecology and population structure of $R$. michauxii for management purposes.

This study was undertaken to determine the $R$. michauxii density in colonies on Fort Pickett, which has a critical role in

maintaining the success of the population. Stem number was chosen as the most practical population measure given time

and budget constraints and because of $R$. michauxii's rhizomatous nature. As a result, the stem density does not reflect the

number of genets in the population.

Colonies were systematically sampled, using $2.5 \mathrm{~m} 2$ quadrats, for density of $R$. michauxii stems. The number of males, females, and gender-neutral stems were tallied in each quadrat. Mean density of $R$. michauxii stems was $1.39 \mathrm{stems} / \mathrm{m} 2(+/-$ $0.25)$. The density of flowering stems was significantly $(P<0.05)$ lower than gender-neutral stems. These findings were consistent with data from North Carolina populations.

14. SUBJECT TERMS

endangered species

natural resource management

Fort Pickett Military Reservation, VA

\begin{tabular}{|c|c|c|}
\hline $\begin{array}{c}\text { 17. SECURITY CLASSIFICATION } \\
\text { OF REPORT } \\
\text { Unclassified }\end{array}$ & $\begin{array}{c}\text { 18. SECURITY CLASSIFICATION } \\
\text { OF THIS PAGE } \\
\text { Unclassified }\end{array}$ & $\begin{array}{c}\text { 19. SECURITY CLASSIFICATION } \\
\text { OF ABSTRACT } \\
\text { Unclassified }\end{array}$ \\
\hline
\end{tabular}

NSN 7540-01-280-5500

\begin{tabular}{|c|c|}
\hline & $\begin{array}{l}\text { 15. NUMBER OF PAGES } \\
18\end{array}$ \\
\hline & 16. PRICE CODE \\
\hline $\begin{array}{l}\text { 19. SECURITY CLASSIFICATION } \\
\text { OF ABSTRACT } \\
\text { Unclassified }\end{array}$ & $\begin{array}{l}\text { 20. LIMITATION OF } \\
\text { ABSTRACT } \\
\text { SAR }\end{array}$ \\
\hline
\end{tabular}




\section{Foreword}

This study was conducted for Commander, U.S. Army Garrison Fort Pickett under Military Interdepartmental Purchase Request (MIPR) No. 6JCERL0413, Work Unit VB6, "Proposal for Stem Counts of Rhus michauxii at Fort Pickett, Virginia." The technical monitor was Alan Dyck, AFRC-FMP-PW.

The work was performed by Verl Emrick of the Natural Resource Assessment and Management Division (LL-N) of the Land Management Laboratory (LL), U.S. Army Construction Engineering Research Laboratories (USACERL). The USACERL principal investigator was Dr. Alison Hill. Dr. David J. Tazik is Acting Chief, CECER-LL-N; Dr. William D. Severinghaus is Operations Chief, CECER-LL; and William D. Goran is the responsible Technical Director, CECER-LL. The USACERL technical editor was Linda L. Wheatley, Technical Information Team.

This research was supported, in part, by an appointment to the Research Participation Program at USACERL, administered by the Oak Ridge Institute for Science and Education through an interagency agreement between the U.S. Department of Energy and USACERL. The authors also wish to acknowledge William Sybold and Patrick Guertin, both of USACERL LL-N, for their assistance in field data collection.

Dr. Michael J. O'Connor is Director of USACERL. 


\section{Contents}

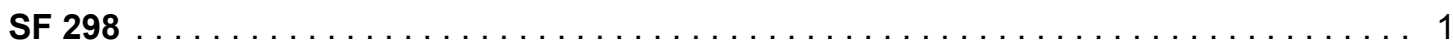

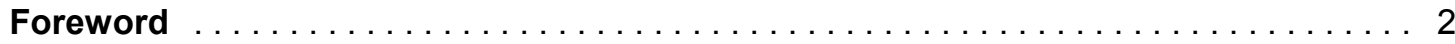

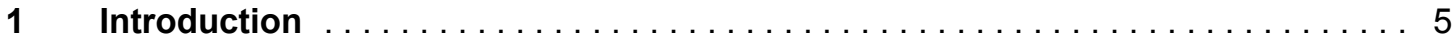

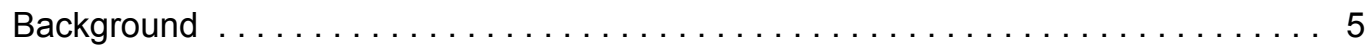

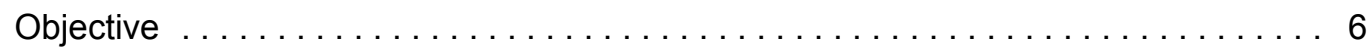

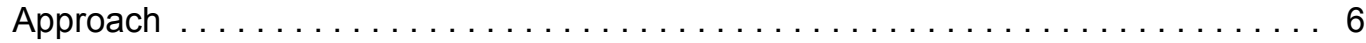

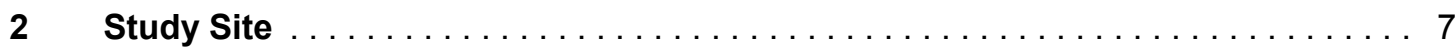

Physical Setting and Climate $\ldots \ldots \ldots \ldots \ldots \ldots \ldots \ldots \ldots \ldots \ldots \ldots \ldots \ldots$

Vegetation $\ldots \ldots \ldots \ldots \ldots \ldots \ldots \ldots \ldots \ldots \ldots \ldots \ldots \ldots \ldots \ldots \ldots \ldots \ldots$

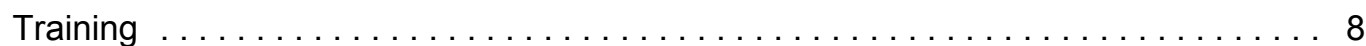

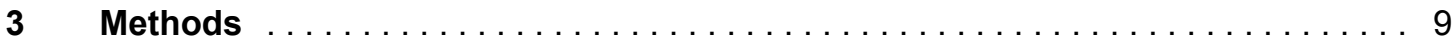

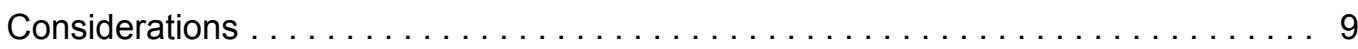

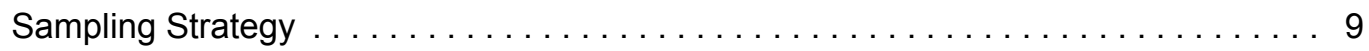

Data Analysis . . . . . . . . . . . . . . . . . . . . . . . . . . 10

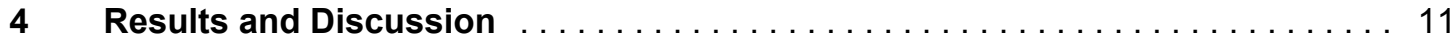

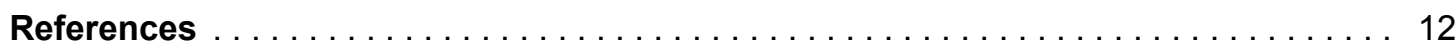

Appendix: Distribution and Size of Sample R. Michauxii Colonies at Fort Pickett . . . . . 14

Distribution 


\section{Introduction}

\section{Background}

Michaux's sumac (Rhus michauxii Sargent) is a dioecious, entomophilous, rhizomatous shrub, in the Anacardiaceae family. The entire plant is densely pubescent and typically 1.5 to $4 \mathrm{dm}$ in height (Radford, Ahles, and Bell 1968, Hardin and Phillips 1985a). Michaux's sumac was first described by Sargent (1895) who considered it “... one of the most poisonous plants in North America." It has subsequently been found to be nonpoisonous, hence one of its colloquial names, False poison sumac.

Genetic and taxonomic studies have shown a close phylogenetic relationship between $R$. michauxii and $R$. glabra L., or Smooth sumac (Hardin and Phillips 1985b, Burke and Hamrick 1995, Sherman-Broyles et al. 1992). Sherman-Broyles et al. suggested that $R$. glabra might, in fact, be the progenitor of $R$. michauxii. The flowering times of $R$. michauxii and $R$. glabra are known to overlap by a third (Radford, Ahles, and Bell 1968). As a result, an interspecific hybrid has been observed in situ and been cultivated and studied in greenhouse experiments (Hardin and Phillips 1985b). At Fort Pickett, several authors have identified morphologically intermediate plants, which were believed to be interspecific hybrids (Fleming and Van Alstine 1994, Smith and Van Alstine 1995, Emrick and Proffitt 1996a).

R. michauxii was designated as endangered by the U.S. Fish and Wildlife Service (USFWS) on 30 October 1989 (USFWS 1993). North Carolina, Georgia, and Virginia list $R$. michauxii as endangered, while South Carolina considers it of "National Concern," though it has apparently been extirpated from the state (Russo 1993). R. michauxii's former range was from north-central Florida to Virginia, where it occurred in the inner coastal plain and lower piedmont of the southeastern Atlantic states. At the time of this study, 26 populations were known, of which 24 occurred in North Carolina and one each in Virginia and Georgia (Russo 1993). The Virginia population (on Fort Pickett) is thought to be the largest population and is composed of numerous subpopulations.

Between 1994 and 1996, previous efforts had: (1) identified and documented the locations of all known colonies of $R$. michauxii at Fort Pickett (Fleming and Van 
Alstine 1994, Smith and Van Alstine 1995, unpublished Fort Pickett fish and wildlife distribution maps), (2) estimated populations through visual reconnaissance (Fleming and Van Alstine 1994, Smith and Van Alstine 1995, and Emrick and Proffitt 1996b), and (3) described the community structure and composition (Emrick and Proffitt 1996a).

\section{Objective}

Before this study, no quantitative assessment of $R$. michauxii density at Fort Pickett had been made. The purpose of this study was to determine the mean density of $R$. michauxii stems in the known colonies at Fort Pickett. These calculations could then be extrapolated to estimate the total number of stems across the installation. This study was undertaken to partially fulfill a USFWS request for a quantitative estimate of the number of stems of $R$. michauxii.

\section{Approach}

To meet the stated objective, these five steps were followed:

1. determination of appropriate method

2. allocation of plots

3. field data gathering

4. data analysis

5. reporting. 


\section{Study Site}

\section{Physical Setting and Climate}

Fort Pickett is in southeastern Virginia approximately $100 \mathrm{~km}$ southwest of Richmond, VA, near the town of Blackstone. The installation covers 18,282 ha (181 $\mathrm{km}^{2}$ ) in portions of three counties: Nottoway, Dinwiddie, and Brunswick. The installation is characterized by gently rolling topography and elevations ranging from 60 to $130 \mathrm{~m}$ above sea level. Approximately 210 ha are ponds and reservoirs, and 200 ha are wetlands. Soils are generally well-drained, nutrient-poor, sandy loams that are susceptible to drought. $R$. michauxii colonies are located primarily in Nottoway and Dinwiddie counties, with two small colonies in Brunswick County.

The winters in the region are mild, and the summers are hot and humid. Seasonal mean temperatures are: $14{ }^{\circ} \mathrm{C}$ in spring, $25^{\circ} \mathrm{C}$ in summer, $16{ }^{\circ} \mathrm{C}$ in autumn, and $4{ }^{\circ} \mathrm{C}$ in winter. Average relative humidity is 54 percent. Rainfall is evenly distributed throughout the year and averages 102+ cm (Fleming and Van Alstine, 1994).

\section{Vegetation}

Fort Pickett is in the Piedmont physiographic region. Major vegetation types occurring at Fort Pickett are those typical of the southeastern Piedmont. The fort falls within the oak/pine/hickory association described by Barbour and Billings (1988). Xeric upland forests are dominated by Quercus spp., Carya spp., Pinus taeda L. and Liquidambar styraciflua L., with the many open areas containing a mixture of herbs, forbs, and grasses typical of the lower Piedmont. Liriodendron tulipifera L., and Platanus occidentalis L. are common mesic forest and flood plain species.

Nearly all of the $R$. michauxii colonies occur within a 4,251-ha Controlled Access Area (CAA). This CAA serves as a buffer zone for the large live-fire range complex that supports various small arms, tank, and artillery training. Throughout the installation's 54-yr history, tactical arms training resulted in wildfires that burned the CAA annually or biannually. These military training fires were allowed to burn 
unhindered within the CAA. As a result, a unique mosaic of pyric disclimax plant communities developed within the CAA (Fleming and Van Alstine 1994, Emrick and Proffitt 1996b).

Colonies of $R$. michauxii occurred in two community associations at Fort Pickett with distinctive differences in plant community structure and composition (Emrick and Proffitt 1996a). Community I, a Quercus falcata (Mich.) / Quercus alba (L.) Liquidambar styraciflua / Carya tomentosa (Poiret) - Schizachyrium scoparium woodland community, had a mean tree canopy $(6+\mathrm{m})$ cover of 40 percent and a sparse shrub strata (1 to $6 \mathrm{~m}$ ) composed primarily of a coppice growth of Liquidambar styraciflua and Quercus spp. The herbaceous strata $(<1 \mathrm{~m})$ was dominated by a mixture of herbs, forbs, and $S$. scoparium, a warm season grass. $R$. michauxii, considered a subdominant in this community association, had a mean cover of 12.5 percent in the herbaceous strata. Community II, a Carya tomentosa / Quercus velutina - S. scoparium /Lespedeza cuneata (Dumont) - R. michauxii/S. scoparium /Lespedeza cuneata open shrubland, was essentially an ecotonal community with virtually no tree canopy cover. The shrub strata consisted of a coppice growth of Carya species and Quercus species. Herbs, forbs, and grasses grew luxuriantly in this open community and often reached heights in excess of $1 \mathrm{~m}$. They accounted for much of the cover in the shrub strata. $R$. michauxii was the dominant species in the herbaceous strata in community II and had the highest mean cover (41 percent). Colonies in community II were impacted by military disturbance to a greater degree than colonies in community I. Old impact craters, shell fragments, and dud ammunition were observed frequently in colonies in community II. Fire scarred and mechanically damaged vegetation was also more prevalent in community II.

\section{Training}

Fort Pickett's mission is to provide maneuver and training areas including live-fire tank and artillery ranges for Army Reserve components, Army National Guard, and units of the Active Army and other military services. In addition to the large range complex discussed above, approximately 10,120 ha of land are available for infantry, armor, and mechanized training. 


\section{Methods}

\section{Considerations}

Before field sampling was undertaken, researchers had to consider several issues:

1. The two definitions of population:

a. the total number of the individuals of a particular species, race, or form of animal or plant inhabiting a particular locality or region

b. the total number of breeding individuals of a species in a particular region.

2. The clonal growth habit of $R$. michauxir: Because of the clonal growth habit of $R$. michauxii, distinguishing individual genets was impossible. As a result, only stems (ramets) were counted.

3. The definition of a colony: $R$. michauxii colonies ranged in size from a few square meters to several hectares. In some cases, the large size and irregular nature of these colonies led to difficulties in designating where one colony ended and another began. As a result, some of the larger colonies were compartmentalized using topographic and cultural features to define colony boundaries.

4. Distinction between $R$. michauxii, $R$. glabra, and hybrids: Stems that exhibited intermediate phenotypic characteristics between $R$. glabra and $R$. michauxii were thought to be hybrids and were not considered.

5. Time: Only two periods were available when the military training schedules allowed constant access to the CAA. This factor severely restricted time available for field sampling.

\section{Sampling Strategy}

Sampling all of the $R$. michauxii colonies was not possible because of the short time allotted for field work (e.g., the first week in July and the last week in August). In general, the survey focused on the larger colonies first and, if time permitted, on the successively smaller colonies. Sampling decisions were made to take advantage of 
previous efforts, support future efforts, and to make the most of the short field access time. To achieve this goal, sampling was prioritized in the following manner:

1. All colonies that were sampled by Emrick and Proffitt (1996a) for community structure and composition were sampled for density of $R$. michauxii stems

2. Large colonies (>2000 stems) identified in previous work

3. Colonies located on tank ranges

4. Small colonies located outside the CAA and of special interest to natural resource managers.

Colonies were marked with flags, and their boundaries were delineated by global positioning systems. In the appendix, Figure A1 is a map showing the locations of the sample colonies, and Table A1 shows the number of sample points within each colony.

Colonies were systematically sampled for density of $R$. michauxii stems. Based on the vegetation type, a $2.5 \mathrm{~m}^{2}$ quadrat was chosen for density measurements (Cain and Castro 1959, Lyon 1968, Bonham 1989). A random point on the colony boundary was chosen and a cardinal direction selected that crossed through the colony. From this initial point, transects were established at $5-\mathrm{m}$ (colonies $<0.5 \mathrm{ha}$ ) or $10^{-\mathrm{m}}$ (colonies $>0.5 \mathrm{ha}$ ) intervals, depending on the size of the colony. The transect number depended on how many transects could cross through the colony at the selected compass bearing. Quadrats were systematically located along these transects every $5 \mathrm{~m}$ (colonies $<0.5 \mathrm{ha}$ ) or $10 \mathrm{~m}$ (colonies $>0.5 \mathrm{ha}$ ); therefore, the number of quadrats depended on the colony size. Random tosses were used to locate the quadrats in two small, irregularly shaped colonies. In very small colonies that were considered unique primarily because of their location, all stems were counted. However, these small unique colonies were not included in the subsequent analysis. Within each quadrat, the number of $R$. michauxii stems at ground level were tallied. In addition, each stem was examined for the presence of male or female flowers, and the number of each was recorded. A total of 410 quadrats were used for the density estimates.

\section{Data Analysis}

Density estimates, expressed as stems $/ \mathrm{m}^{2}$, and corresponding confidence intervals were calculated for total stems, male stems, female stems, and neutral stems. Mean densities of neutral stems were compared with both male and female stems using a paired t-test (Systat 1992). 


\section{Results and Discussion}

Data collected at Fort Pickett represented the first quantitative assessment of $R$. michauxii density. Because of the rhizomatous nature of $R$. michauxii, no attempt was made to distinguish between individuals. Therefore, the mean density was an index of population and not a true population figure. Mean density of $R$. michauxii stems across all colonies was 1.39 stems $/ \mathrm{m}^{2}\{+/-0.25\}$ (Table 1 ). This mean was for the entire population, so individual colony densities varied.

The manner of data collection was greatly affected by the time constraints imposed upon field sampling by military training activities and the danger that unexploded ordnance posed. Therefore, none of the transects were permanently marked with steel pins or other similar devices. However, all colony boundaries and number of sample quadrats located within each colony were archived in the Fort Pickett Fish and Wildlife geographic information system data base. As a result, the colonies can be resurveyed using the same colony boundaries and quadrats. This data base will allow natural resource managers to track changes in $R$ michauxii stem density over time.

Russo (1993) reported that over half the stems in North Carolina populations did not flower, which was also the case in the Fort Pickett population. Densities for neutral, female, and male stems are reported in Table 1. Overall, the density of neutral stems was significantly higher $(\mathrm{P}<0.05)$ than either female or male stems, but there was no significant difference in the density of male and female stems. However, only 9 of the 23 colonies (39 percent) sampled had both male and female stems. Nevertheless, this was a higher percentage than that reported by Savage and Bucher (1991) in North Carolina populations.

Table 1. Density of Rhus michauxii stems expressed as number of stems $/ \mathrm{m}^{2}$.

\begin{tabular}{|lccc|}
\hline \multicolumn{1}{|c}{ Variable } & $\mathbf{N}$ & Sample Mean & 95\% Confidence Interval \\
\hline Total Stems & 410 & 1.386 & $+/-0.251$ \\
Neutral Stems & 410 & $1.046 \#$ & $+/-0.142$ \\
Female Stems & 410 & $0.163^{*}$ & $+/-0.026$ \\
Male Stems & 410 & $0.192^{*}$ & $+/-0.028$ \\
\hline * Denotes sample mean significantly $(P<0.05)$ lower than \#. \\
\hline
\end{tabular}




\section{References}

Barbour, Michael G., and William Dwight Billings, North American Terrestrial Vegetation (Cambridge University Press, 1988).

Bonham, Charles D., Measurements for Terrestrial Vegetation (John Wiley \& Sons, New York, NY, 1989).

Burke, J.M., and J.L. Hamrick, Evidence of Hybridization Between Rhus michauxii and Rhus glabra, unpublished manuscript (University of Georgia, 1995).

Cain, S.A., and G.M. Castro, Manual of Vegetation Analysis (Harper and Bros., New York, 1959).

Emrick, Verl R., and Robert Proffitt, The Community Ecology of Rhus michauxii at Fort Pickett Military Reservation Virginia, unpublished manuscript, 1996a.

Emrick, Verl R., and Robert Proffitt, Summarization of the Land Condition Trends Analysis (LCTA) Program at Fort Pickett Military Reservation for the Years 1994 and 1995, unpublished report (Fort Pickett Fish and Wildlife Management Branch, 1996b).

Fleming, G.P., and N.E. Van Alstine, A Natural Heritage Inventory of Fort Pickett, VA, Natural Heritage Technical Report 94-3, Virginia Department of Conservation and Recreation, Division of Natural Heritage, Richmond, VA. Unpublished report submitted to U.S. Army Garrison, Fort Pickett, June 1994.

Hardin, James W., and Lyle L. Phillips, "Hybridization in Eastern North American Rhus (Anacardiaceae)," Association of Southeastern Biologists Bulletin, vol 32 (1985a), pp 99106.

Hardin, James W., and Lyle L. Phillips, "Atlas of Foliar Surface Features in Woody Plants, VII. Rhus subg. Rhus (Anacardiaceae) of North America," Bulletin of the Torrey Botanical Club, vol 112 (1985b), pp 1-10.

Lyon, L.J., "An Evaluation of Density Sampling Methods in a Shrub Community," J. Range Management, vol 21 (1968), pp 16-20.

Radford, A.E., H.E. Ahles, and C.R Bell, Manual of the Vascular Flora of the Carolinas (The University of North Carolina Press, Chapel Hill, 1968). 
Russo, Mary J., Rhus michauxii Element Stewardship Abstract, unpublished manuscript (North Carolina Natural Heritage Program, Sandhills Field Office, 1993).

Sargent, C.S., "New or Little Known Plants; Rhus michauxii," Gardens and Forest, vol 398 (1895), pp 404-405.

Savage, Sherry, and Margit Bucher, Preliminary Results of a Demographic and Genetic Analysis of Rhus michauxii, unpublished manuscript (North Carolina Nature Conservancy, 1991).

Sherman-Broyles, Susan L., J. Phil Gibson, J.L. Hamrick, Margit A. Bucher, and M. Jane Gibson, "Comparison of Allozyme Diversity Among Rare and Widespread Rhus Species," Systematic Botany, vol 17 (1992), pp 551-559.

Smith, T.L., and N.E. Van Alstine, Distribution of Rhus michauxii of Fort Pickett, Virginia, Natural Heritage Technical Report 95-15, Virginia Department of Conservation and Recreation, Division of Natural Heritage, Richmond, VA. Unpublished report submitted to the U.S. Army (October 1995).

Systat, Inc., Systat for Windows: Statistics, Version 5 Edition (Evanston, IL, 1992).

U.S. Fish and Wildlife Service, Michaux's Sumac Recovery Plan (Atlanta, GA, 1993). 


\section{Appendix: Distribution and Size of Sample R. Michauxii Colonies at Fort Pickett}

Table A1. Number of quadrats sampled in each colony.

\begin{tabular}{|ccc|}
\hline Colony \# & \# of Quadrats & Size $\left(\mathbf{m}^{2}\right)$ \\
\hline 2 & 42 & $1,992.2$ \\
3 & 19 & 683.2 \\
4 & 13 & 498.9 \\
7 & 6 & 159.4 \\
8 & 10 & 405.3 \\
9 & 5 & 231.8 \\
13 & 77 & $16,568.2$ \\
15 & 28 & $1,126.5$ \\
16 & 33 & $1,282.9$ \\
17 & 8 & 132.8 \\
20 & 12 & 206.1 \\
21 & 17 & 242.6 \\
22 & 15 & 337.2 \\
23 & 26 & $3,780.8$ \\
24 & 12 & $1,773.8$ \\
25 & 8 & 142.1 \\
26 & 30 & $3,432.6$ \\
27 & 15 & 813.2 \\
28 & 16 & 637.1 \\
29 & 5 & 69 \\
30 & 13 & 379.6 \\
\hline
\end{tabular}




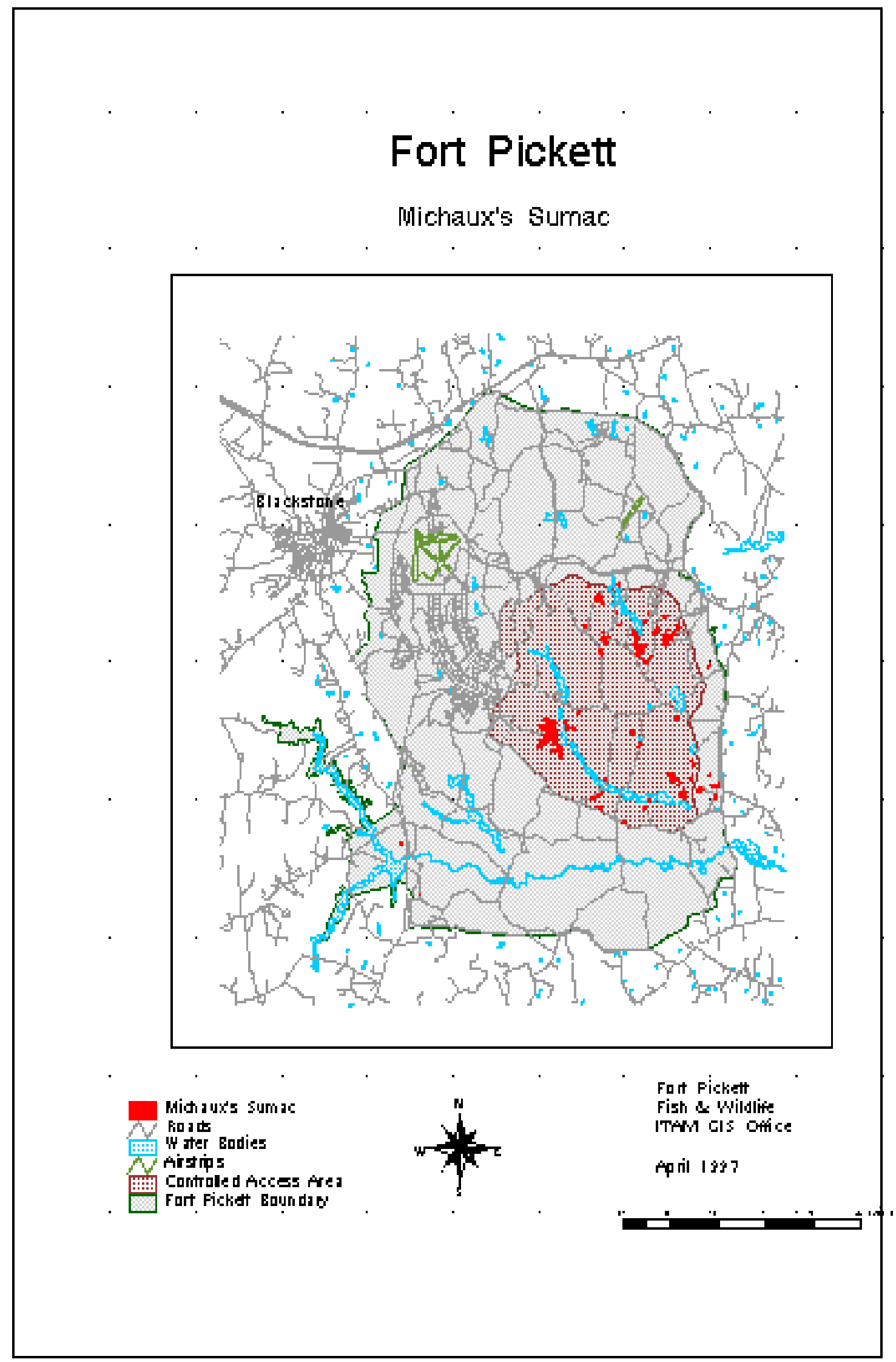

Figure A1. Distribution of known R. Michauxii colonies at Fort Pickett Military Reservation, VA. 